\title{
Assessing Activity Access of Forage or Biomass
}

\author{
D. R. Buckmaster
}

\begin{abstract}
Electrolytic ion leakage is proposed as a method to assess activity access for subsequent biological or chemical processing of forage or biomass. Smaller particle sizes and subsequent processing, which increased surface area, resulted in higher leachate ion conductivity measures. Use of ion conductivity readings to compare harvest or processing treatments requires some normalization because of potentially different chemical composition among samples. Using an abrasive cyclone mill to process a sample for use in determining a normalizing index (which is a ratio of access, relative to ultimate) yielded more consistency among whole-plant corn silage samples than blending. Longitudinal shredding of whole-plant corn silage resulted in higher activity access (as indicated by conductivity index) than precision-cut chopping or chopping plus mechanical roll processing. Shredding at harvest time seems to reduce the need for post-storage processing.
\end{abstract}

Keywords. Biomass, Electrolyte leakage, Fiber, Forage, Harvest, Ion conductivity, Leachate, Particle size, Processing, Surface area.

$\mathrm{D}$ uring harvest and processing of forage and biomass, surface area and particle size distribution are important. Surface area is needed to facilitate biological, chemical, or combustion reactions. In the case of ruminant livestock, high surface area to mass ratio speeds digestion. In bioconversion processes, high surface area speeds reactions. Particle size distribution affects handling and storage properties. Ruminant livestock need effective fiber to maintain rumen health; therefore, particle size distribution is very important as it affects the formation of a rumen mat, regurgitation, saliva flow, and rumen $\mathrm{pH}$. Surface area and particle size are related, but differing methods of material processing affect their interrelationship differently.

Conductivity of electrolytic ions leached into solution has been used in a wide variety of food, feed, and fiber applications. Marks and Stroshine (1998) used electrolyte leakage of stored grain as an indicator of its storability. Low conductivity of leachate would indicate more "sealed" grains with less susceptibility to mold invasion. Susceptibility of soybean cultivar roots to sulfentrazone has also been assessed using conductivity (Zhaohu et al., 2000). Thiaw and Hall (2004) used leaf electrolyte leakage as a plant breeding screening tool; it was related to yield in heat stress conditions. Each of these applications relates low leakage to reduced access to what is inside the product.

Kraus et al. (1999) used ion conductivity of leachate as a correlation to cell rupture with macerated direct-cut forages. Their premise was that higher conditioning levels facilitated more extensive cell rupture, which subsequently leads to more rapid drying and improved digestibility. The cell rupture was assessed via leakage of cell contents into solution.

Submitted for review in May 2007 as manuscript number PM 7008; approved for publication by the Power \& Machinery Division of ASABE in October 2008.

The author is Dennis R. Buckmaster, ASABE Member Engineer, Associate Professor, Department of Agricultural and Biological Engineering, Purdue University, 225 S. University St., West Lafayette, IN 47097-2093; phone: 765-496-9512; fax: 765-496-1115; e-mail: dbuckmas @purdue.edu.
To compare harvest treatments, they computed a normalizing index, which was the ratio of filtered leachate conductivity to the conductivity of a filtered leachate that had been blended. The blending lab treatment was considered to cause "ultimate" access to cell contents.

Rajasekaran and Blake (1999) used electrolyte leakage as an indicator of movement across pine seedling membranes. The index of injury was related to plant stress. For the membrane injury index, leakage of electrolytes from a stressed plant was compared to total electrolytes determined as leakage from heat-killed tissue. Also using heat to destroy membranes, Joy and Lada (2006) computed membrane injury indices of individually quick-frozen cut and peel carrots; this solute leakage was used to determine where in the processing line cellular damage occurs.

To date, most biomass has been harvested with conventional forage machinery, including balers and precision-cut forage harvesters. Other post-harvest particle size reduction methods studied include hammer mills and tub grinders. Shinners et al. (1987) concluded that longitudinal shear of plant material takes much less energy than cross-fiber cutting. Building on this notion, and recognizing the need for longer, more effective fiber for ruminants, Zhang et al. (2003) developed a different corn silage harvest method that primarily uses longitudinal shear. While particle size distribution of shredded silage has much more long particle mass than silage harvested with precision-cut forage harvesters, the shredded silage has a tremendous amount of surface area.

Whether forage or biomass is used in ruminant animals or a biorefinery, access to the plant nutrients is critical for the biological or chemical activity that ensues. A means of assessing activity access is needed; based on the aforementioned applications of leakage of electrolytic ions, ion conductivity holds potential as such an indicator, which can be measured independent of particle size.

\section{ObJectives}

- For three different harvest methods (shredding, chopping, chopping plus mechanical roll processing), determine effects of lab treatments and post-storage 
processing on leachate ion conductivity within four particle size fractions.

- Determine if leachate ion conductivity is related to specific surface area and could be an activity access indicator.

- Determine if abrasive cyclone mill processing yields more consistent and ultimate leachate ion conductivity readings than blending.

- Determine the effects of harvest method (shredding, chopping, chopping plus mechanical roll processing), post-storage processing, and particle size on conductivity index.

\section{Methods and Procedures \\ HARVEST AND STORAGE}

Corn silage was harvested at $55 \%$ to $60 \%$ moisture (w.b.) with three different methods (abbreviated as C, P, and S). Chopped (C) silage was harvested with a precision-cut forage harvester with the theoretical length of cut (TLC) set to $9.5 \mathrm{~mm}$. Chopped and processed (P) silage was harvested with the same harvester with a TLC setting of $19 \mathrm{~mm}$ with the serrated crop processing rolls engaged. Shredded (S) silage was harvested with a shredding harvester (Zhang et al., 2003). Material from each harvest method was stored in three replicate $15 \mathrm{~L}$ laboratory-scale silos prepared similarly to those used by Hoover (1998) with three layers of plastic. The lab silos were stored at room temperatures of $20^{\circ} \mathrm{C}$ to $25^{\circ} \mathrm{C}$ for 1 to 3 months.

\section{LABORATORY Methods}

Three 0.7 L subsamples from each lab-scale silo associated with each harvest method (C, P, and S) were separated into four particle size fractions using the device described by Kononoff et al. (2003); this device has three sieves (19, 8.1, and $1.8 \mathrm{~mm}$ ) and a bottom pan. In addition to the three replicates of these 12 treatments available for lab analysis, three replicates of particle fractions from the upper two sieves (long and medium long) were processed (post-storage) in a Hobart slicing industrial food processor (model 84181D) for $1 \mathrm{~min}$ to simulate livestock chewing or other mechanical particle size reduction, which might occur post-storage in a biorefinery (Hoover, 1998).

The quality of the silage was evaluated on the basis of a wet chemistry analysis conducted by Cumberland Valley Analytical Services in Maugansville, Maryland. Ensiled samples were evaluated for dry matter (DM), crude protein (CP), acid detergent fiber (ADF) (AOAC, 1990), and neutral detergent fiber (NDF) (Goering and Van Soest, 1970).

Ion conductivity of silage leachate was measured using $300 \mathrm{~mL}$ of distilled water at $25^{\circ} \mathrm{C}$ and a $5 \mathrm{~g}$ DM sample that had been oven-dried at $60^{\circ} \mathrm{C}$ (yielding a similar DM to water ratio as that used by Kraus et al., 1999). Prior to addition of sample, the initial conductivity reading was recorded; initial readings were always very small (averaging less than $2 \mu \mathrm{S}$ $\mathrm{cm}^{-1}$ ) and were taken to ensure lab cleanliness and water purity. For the soak and swirl (SS, or "as is") treatment, silage was placed in the water and placed in an agitating incubator set to $25^{\circ} \mathrm{C}$ operating at $150 \mathrm{rpm}$. Based on preliminary (unpublished) data, the silage was allowed to agitate in the water for $30 \mathrm{~min}$ prior to filtering of the solution. At least $100 \mathrm{~mL}$ of solution was filtered (grade 1573 1/2, 12 to $25 \mu \mathrm{m}$ particle retention), and ion conductivity of the leachate was immediately measured using a VWR expanded range digital conductivity meter (model 23226-523). Data were recorded in microSiemens per $\mathrm{cm}(\mu \mathrm{S} \mathrm{cm}-1)$ and expressed as $\left(\mu \mathrm{S} \mathrm{cm} \mathrm{cm}^{-1}\right.$ $\left.\mathrm{g}^{-1}\right)$ allowing for correction for actual sample size and initial (water only) reading as follows:

$$
\mathrm{LIC}=\frac{\mathrm{IC}_{\text {final }}-\mathrm{IC}_{\text {initial }}}{\mathrm{M}_{\text {sample }}}
$$

where

$$
\begin{aligned}
& \text { LIC }= \text { leachate ion conductivity adjusted for sample } \\
& \text { mass }\left(\mu \mathrm{Sm}^{-1} \mathrm{~g}^{-1}\right) \\
& \mathrm{IC}_{\text {final }}= \text { final ion conductivity measurement }\left(\mu \mathrm{S} \mathrm{cm} \mathrm{cm}^{-1}\right) \\
& \mathrm{IC}_{\text {initial }}= \text { initial ion conductivity measurement }(\mu \mathrm{S} \mathrm{cm}-1) \\
& \mathrm{M}_{\text {sample }}= \text { sample mass }(\mathrm{g}) . \\
& \text { Two lab treatments were considered candidates for the de- }
\end{aligned}
$$
nominator of a conductivity index that could indicate relative access to plant nutrients. Kraus et al. (1999) used a blender treatment with wet forage, so a blending treatment was included. Abrasive cyclone grinding was also tested because it yields a relatively uniform and very fine particle size distribution with dry products and is commonly used with near-infrared spectroscopy and other lab procedures.

The blend treatment protocol was similar to soak and swirl: $5 \mathrm{~g}$ DM plus $300 \mathrm{~mL}$ water were agitated for $5 \mathrm{~min}$, blended in a Waring commercial blender (model 51BL30, $1 \mathrm{~L}$ stainless steel containers) for $1 \mathrm{~min}$, and then agitated for the remainder of $30 \mathrm{~min}$. For the abrasive cyclone mill treatment, samples were ground in an abrasive cyclone mill (model 3010-080P, UDY Corp., Fort Collins, Colo.) with a $1 \mathrm{~mm}$ screen. A $5 \mathrm{~g} \mathrm{DM}$ subsample was then placed into the water and agitated in the $25^{\circ} \mathrm{C}$ incubator for $30 \mathrm{~min}$ as with the other treatments. LIC was determined for three replicates of each sample processed in each manner.

Conductivity index of a sample based on these lab methods was computed as follows:

$$
\begin{aligned}
& \mathrm{CI}_{\mathrm{U}}=\frac{\mathrm{LIC}_{\mathrm{SS}}}{\mathrm{LIC}_{\mathrm{U}}} \\
& \mathrm{CI}_{\mathrm{B}}=\frac{\mathrm{LIC}_{\mathrm{SS}}}{\mathrm{LIC}_{\mathrm{B}}}
\end{aligned}
$$

where CI is the conductivity index. Subscript U refers to a sample processed with the abrasive cyclone mill (UDY Corp.) for leachate ion conductivity measurement; subscript SS refers to the soak and swirl measurement of leachate ion conductivity; and subscript B refers to a blended sample for leachate ion conductivity measurement.

\section{Results AND Discussion}

\section{INITIAL Quality}

Initial quality, expressed as $\mathrm{CP}, \mathrm{NDF}$, and ADF, of the silage and separated particle size fractions are given in tables 1,2 , and 3 , respectively. Data were analyzed by one-way ANOVA with Tukey's method used to determine significant differences among treatments. Whole (non-separated) samples were no different $(\mathrm{p}<0.05)$, regardless of which quality measure was considered (tables 1, 2, and 3; $\mathrm{p}<0.05$ ); $\mathrm{CP}$ ranged from $6.53 \%$ to $6.86 \%$, NDF ranged from $37.1 \%$ to 
Table 1. Initial crude protein concentration of unseparated samples and different particle size fractions of whole-plant corn silage harvested with three different methods (\% of DM).[a]

\begin{tabular}{|c|c|c|c|c|c|}
\hline & \multirow[b]{2}{*}{$\begin{array}{c}\text { Unseparated } \\
\text { Sample }\end{array}$} & \multicolumn{4}{|c|}{ Particle Size ${ }^{[\mathrm{b}]}$} \\
\hline & & Long & $\begin{array}{l}\text { Medium } \\
\text { Long }\end{array}$ & $\begin{array}{l}\text { Medium } \\
\text { Small }\end{array}$ & Small $^{[c]}$ \\
\hline Chopped (C) & $6.86 \mathrm{a}$ & $4.11 \mathrm{a}$ & 6.83 & 7.00 & 8.15 \\
\hline $\begin{array}{l}\text { Chopped and } \\
\text { processed }(\mathrm{P})\end{array}$ & $6.53 \mathrm{a}$ & 5.94 & $6.28 \mathrm{a}$ & 8.22 & 8.18 \\
\hline Shredded (S) & $6.69 \mathrm{a}$ & $3.77 \mathrm{a}$ & $6.03 \mathrm{a}$ & 7.49 & 7.62 \\
\hline
\end{tabular}

[a] Values within a column followed by the same letter are not different (Tukey's method, $\mathrm{p}<0.05)$.

[b] Contents of three sieves $(19,8.1$, and $1.8 \mathrm{~mm})$ and pan of device described by Kononoff et al. (2003).

[c] Insufficient data on pan contents to perform statistical analysis.

Table 2. Initial neutral detergent fiber concentration of unseparated samples and different particle size fractions of whole-plant corn silage harvested with three different methods (\% of DM). ${ }^{[a]}$

\begin{tabular}{|c|c|c|c|c|c|}
\hline & \multirow[b]{2}{*}{$\begin{array}{c}\text { Unseparated } \\
\text { Sample }\end{array}$} & \multicolumn{4}{|c|}{ Particle Size ${ }^{[\mathrm{b}]}$} \\
\hline & & Long & $\begin{array}{l}\text { Medium } \\
\text { Long }\end{array}$ & $\begin{array}{l}\text { Medium } \\
\text { Small }\end{array}$ & $\operatorname{Small}^{[\mathrm{c}]}$ \\
\hline Chopped (C) & $37.9 \mathrm{a}$ & $60.4 \mathrm{~b}$ & 36.6 & 36.6 & 24.4 \\
\hline $\begin{array}{l}\text { Chopped and } \\
\text { processed }(\mathrm{P})\end{array}$ & $37.1 \mathrm{a}$ & $62.7 \mathrm{ab}$ & $41.8 \mathrm{a}$ & 25.4 & 21.7 \\
\hline Shredded (S) & $37.7 \mathrm{a}$ & $65.0 \mathrm{a}$ & $46.2 \mathrm{a}$ & 29.2 & 23.2 \\
\hline
\end{tabular}

[a] Values within a column followed by the same letter are not different (Tukey's method, $\mathrm{p}<0.05$ ).

[b] Contents of three sieves $(19,8.1$, and $1.8 \mathrm{~mm})$ and pan of device described by Kononoff et al. (2003).

[c] Insufficient data on pan contents to perform statistical analysis.

Table 3. Initial acid detergent fiber concentration of unseparated samples and different particle size fractions of whole-plant corn silage harvested with three different methods (\% of DM). ${ }^{[a]}$

\begin{tabular}{lccccc}
\hline & & \multicolumn{4}{c}{ Particle Size ${ }^{[\mathrm{b}]}$} \\
\cline { 3 - 6 } & $\begin{array}{c}\text { Unseparated } \\
\text { Samples }\end{array}$ & Long & $\begin{array}{c}\text { Medium } \\
\text { Long }\end{array}$ & $\begin{array}{c}\text { Medium } \\
\text { Small }\end{array}$ & Small[c] \\
\hline Chopped (C) & $20.1 \mathrm{a}$ & $32.5 \mathrm{a}$ & 19.4 & 20.7 & 13.6 \\
$\begin{array}{c}\text { Chopped and } \\
\text { processed (P) }\end{array}$ & $20.4 \mathrm{a}$ & $33.0 \mathrm{a}$ & $22.7 \mathrm{a}$ & 12.2 & 11.2 \\
Shredded (S) & $20.6 \mathrm{a}$ & 39.6 & $24.0 \mathrm{a}$ & 14.5 & 12.4 \\
\hline
\end{tabular}

[a] Values within a column followed by the same letter are not different (Tukey's method, $\mathrm{p}<0.05)$.

[b] Contents of three sieves $(19,8.1$, and $1.8 \mathrm{~mm})$ and pan of device described by Kononoff et al. (2003).

[c] Insufficient data on pan contents to perform statistical analysis.

$37.9 \%$, and ADF ranged from $20.1 \%$ to $20.6 \%$. Harvest method did not affect overall quality.

However, the particle size fractions differed in chemical quality; this is because different particle size fractions contain different proportions of the whole-plant corn silage constituents (grain, cob, stalk, leaf). Furthermore, proportions of these silage constituents within a particle size range will vary with harvest method. Within the long particle range, $\mathrm{CP}$ from P $(5.94 \%)$ was higher than CP from C $(4.11 \%)$ or S $(3.77 \%)$ (table $1 ; \mathrm{p}<0.05)$. For the medium long particle range, $\mathrm{CP}$ was higher for $\mathrm{C}(6.83 \%)$ than $\mathrm{P}(6.28 \%)$ or S $(6.03 \%)$. Fiber concentrations were higher in the long particles from $\mathrm{S}$ (65.0\% NDF, 39.6\% ADF) and P (62.7\% NDF, 33.0\% ADF) silage than in long particles from $\mathrm{C}(60.4 \% \mathrm{NDF}, 32.5 \%$ ADF) silage. Similarly, the medium long particles from $\mathrm{S}$ (46.2\% NDF, 24.0\% ADF) and P (41.8\% NDF, 22.7\% ADF) silage had higher fiber concentrations than the medium long

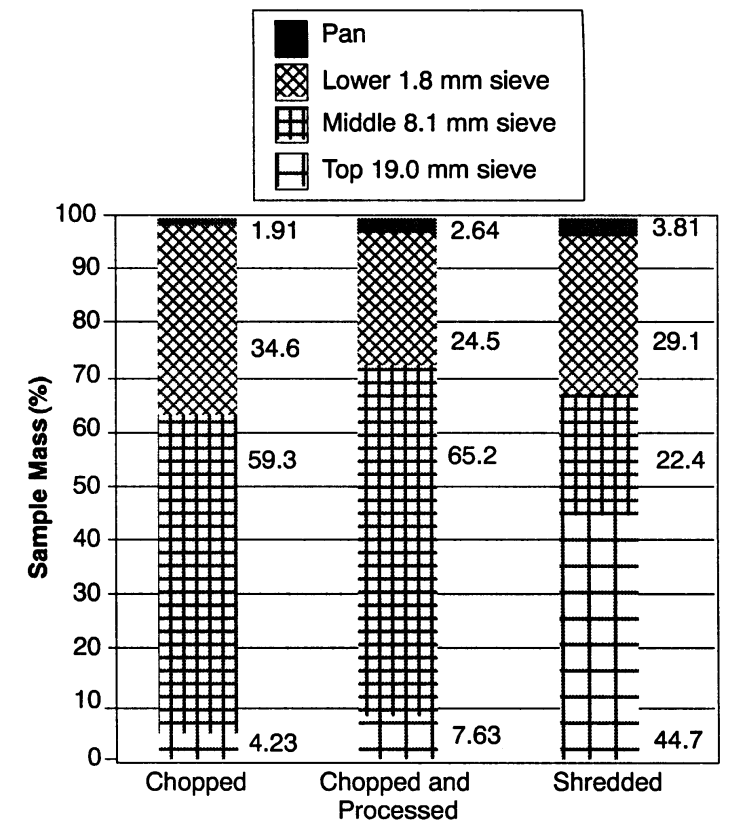

Figure 1. Particle size distribution of whole-plant corn silage harvested with three different methods (using device described by Kononoff et al., 2003).

particles from C (36.6\% NDF, $19.4 \%$ ADF) silage. Sample size was insufficient to obtain laboratory replication and allow statistical comparison of chemical quality of small particles, but the fiber concentrations of medium small particles from $\mathrm{P}$ (25.4\% NDF, $12.2 \% \mathrm{ADF})$ and S (29.2\% NDF, $14.5 \%$ $\mathrm{ADF})$ silage were lower than that from C (36.6\% NDF, $20.7 \%$ ADF) silage. Because chemical attributes were different in various particle size fractions from a harvest treatment, direct comparisons of leachate ion conductivity should be avoided. Comparisons of leachate ion conductivity will need to be normalized in some manner that accounts for the chemical attributes of the material being leached.

\section{Particle Size Distributions}

Figure 1 illustrates the particle size distributions of the silage harvested with the three methods. Chopped and processed (P) silage had more long material (7.63\%) than $\mathrm{C}$ (4.23\%). More significant, however, is the long material from the shredded silage. The percentage of long material $(44.7 \%$ $>19 \mathrm{~mm}$ in length) from $\mathrm{S}$ was at approximately 10 times higher than that from $\mathrm{C}(4.23 \%)$ and 6 times higher than that from P (7.63\%) silage. Zhang et al. (2003) reported similar particle size distributions with a different, yet similar, device.

\section{Particle Size Reduction InCreased Leachate CONDUCTIVITY}

Tables 4 through 7 include data showing the effects of lab treatment and post-storage processing on LIC measures of particles of varying size taken from whole-plant corn silage harvested with three different methods. As samples were processed in the lab (Hobart, blending, or abrasive cyclone mill), particle size was reduced. The dramatic size reduction of relatively larger particles caused by blending or abrasive cyclone milling was commensurately associated with an increase in specific surface area. For long particles from $\mathrm{C}$, there was an $88 \%$ increase in LIC as lab method went from 
Table 4. Effect of lab treatment on leachate ion conductivity $\left(\mu \mathrm{cm}^{-1} \mathrm{~g}^{-1}\right)$ of long particles ${ }^{[a]}$ from whole-plant corn silage harvested with three different methods. ${ }^{[b]}$

\begin{tabular}{lccc}
\hline & $\begin{array}{c}\text { Chopped } \\
\text { (C) }\end{array}$ & $\begin{array}{c}\text { Chopped and } \\
\text { Processed (P) }\end{array}$ & $\begin{array}{c}\text { Shredded } \\
(\mathrm{S})\end{array}$ \\
\hline Soak and swirl (SS) & $121 \mathrm{a}$ & 178 & 169 \\
Hobart & $172 \mathrm{~b}$ & $227 \mathrm{a}$ & $220 \mathrm{a}$ \\
Blended (B) & $152 \mathrm{ab}$ & $231 \mathrm{a}$ & $220 \mathrm{a}$ \\
Abrasive cyclone mill (U) & 227 & $237 \mathrm{a}$ & $225 \mathrm{a}$ \\
\hline
\end{tabular}

[a] Top $(19 \mathrm{~mm})$ sieve contents of device described by Kononoff et al. (2003).

[b] Values within a column followed by the same letter are not different (Tukey's method, $\mathrm{p}<0.05$ ).

Table 5. Effect of lab treatment on leachate ion conductivity $\left(\mu \mathrm{cm}^{-1} \mathrm{~g}^{-1}\right)$ of medium long particles ${ }^{[a]}$ from whole-plant corn silage harvested with three different methods. ${ }^{[b]}$

\begin{tabular}{lccc}
\hline & $\begin{array}{c}\text { Chopped } \\
(\mathrm{C})\end{array}$ & $\begin{array}{c}\text { Chopped and } \\
\text { Processed (P) }\end{array}$ & $\begin{array}{c}\text { Shredded } \\
(\mathrm{S})\end{array}$ \\
\hline Soak and swirl (SS) & 144 & $132 \mathrm{a}$ & $172 \mathrm{a}$ \\
Hobart & $175 \mathrm{a}$ & $171 \mathrm{ab}$ & $195 \mathrm{ab}$ \\
Blended (B) & $189 \mathrm{a}$ & $183 \mathrm{~b}$ & $212 \mathrm{~b}$ \\
Abrasive cyclone mill (U) & $192 \mathrm{a}$ & $194 \mathrm{~b}$ & $206 \mathrm{~b}$ \\
\hline
\end{tabular}

[a] Middle $(8.1 \mathrm{~mm})$ sieve contents of device described by Kononoff et al. (2003).

[b] Values within a column followed by the same letter are not different (Tukey's method, $\mathrm{p}<0.05$ ).

Table 6. Effect of lab treatment on leachate ion conductivity $\left(\mu \mathrm{Sm}^{-1} \mathrm{~g}^{-1}\right)$ of medium small particles ${ }^{[a]}$ from whole-plant corn silage harvested with three different methods. ${ }^{[b]}$

\begin{tabular}{lccc}
\hline & $\begin{array}{c}\text { Chopped } \\
\text { (C) }\end{array}$ & $\begin{array}{c}\text { Chopped and } \\
\text { Processed (P) }\end{array}$ & $\begin{array}{c}\text { Shredded } \\
(\mathrm{S})\end{array}$ \\
\hline Soak and swirl (SS) & $163 \mathrm{a}$ & $115 \mathrm{a}$ & $159 \mathrm{a}$ \\
Blended (B) & $180 \mathrm{a}$ & $135 \mathrm{a}$ & $181 \mathrm{a}$ \\
Abrasive cyclone mill (U) & $186 \mathrm{a}$ & $133 \mathrm{a}$ & $185 \mathrm{a}$ \\
\hline
\end{tabular}

[a] Lower $(1.8 \mathrm{~mm})$ sieve contents of device described by Kononoff et al. (2003).

[b] Values within a column followed by the same letter are not different (Tukey's method, $\mathrm{p}<0.05$ ).

Table 7. Effect of lab treatment on leachate ion conductivity $\left(\mu \mathrm{cm}^{-1} \mathrm{~g}^{-1}\right)$ of small particles ${ }^{[\mathrm{a}]}$ from whole-plant corn silage harvested with three different methods. ${ }^{[b]}$

\begin{tabular}{lccc}
\hline & $\begin{array}{c}\text { Chopped } \\
\text { (C) }\end{array}$ & $\begin{array}{c}\text { Chopped and } \\
\text { Processed (P) }\end{array}$ & $\begin{array}{c}\text { Shredded } \\
\text { (S) }\end{array}$ \\
\hline Soak and swirl (SS) & $148 \mathrm{a}$ & $144 \mathrm{a}$ & $158 \mathrm{a}$ \\
Blended (B) & $155 \mathrm{a}$ & 150 & $173 \mathrm{a}$ \\
Abrasive cyclone mill (U) & $149 \mathrm{a}$ & $144 \mathrm{a}$ & $164 \mathrm{a}$ \\
\hline [a] Pan contents of device described by Kononoff et al (2003)
\end{tabular}

[a] Pan contents of device described by Kononoff et al. (2003)

[b] Values within a column followed by the same letter are not different (Tukey's method, $\mathrm{p}<0.05$ ).

Table 8. Effect of lab treatment on coefficient of variation of leachate ion conductivity for particles of different size.

\begin{tabular}{|c|c|c|c|}
\hline Particle Size ${ }^{[a]}$ & $\mathrm{CV}_{\mathrm{B}}(\%)^{[\mathrm{b}]}$ & $\mathrm{CV}_{\mathrm{U}}(\%)$ & $\mathrm{p}^{[\mathrm{c}]}$ \\
\hline Long & 5.33 & 1.63 & 0.032 \\
\hline Medium long & 5.52 & 1.90 & 0.076 \\
\hline Medium small & 7.66 & 2.89 & 0.137 \\
\hline Small & 3.43 & 2.55 & NS \\
\hline
\end{tabular}

[a] Contents of three sieves $(19,8.1$, and $1.8 \mathrm{~mm})$ and pan of device described by Kononoff et al. (2003).

[b] $\mathrm{CV}=$ coefficient of variation; reported mean is average of 6 coefficients of variation each based on 3 data points from each of the 3 harvest methods (C, P, S) with and without Hobart processing (18 samples total).

[c] Probability of a difference using t-test; NS means $\mathrm{p}>0.25$. soak and swirl $\left(121 \mu \mathrm{S} \mathrm{cm} \mathrm{cm}^{-1} \mathrm{~g}^{-1}\right)$ to abrasive cyclone mill $\left(227 \mu \mathrm{S} \mathrm{cm}^{-1} \mathrm{~g}^{-1}\right)$. The increase was less, yet also significant $(\mathrm{p}<0.05)$, for long particles from P or S. For long particles, regardless of harvest method, post-storage (Hobart) and lab (blending or abrasive cyclone mill) processing, which reduced particle size and increased surface area, increased the LIC above the soak and swirl (as is) value ( $\mathrm{p}<0.05$; table 4 ).

Results were similar for medium long particles (table 5); however, since $\mathrm{P}$ and $\mathrm{S}$ particles were longitudinally sheared more than $\mathrm{C}$ particles, the increase from post-storage Hobart processing (132 to $171 \mu \mathrm{S} \mathrm{cm}^{-1} \mathrm{~g}^{-1}$ for $\mathrm{P}$; 172 to $195 \mu \mathrm{S} \mathrm{cm}^{-1}$ $\mathrm{g}^{-1}$ for $\mathrm{S}$ ) was not significant ( $\mathrm{p}>0.05$ ).

With only one exception (blending of small particles; table 7), neither blending nor abrasive cyclone mill processing of small or medium small particles increased LIC compared to soak and swirl ( $p>0.05$; tables 6 and 7).

The data in tables 4 and 5 illustrate that reduced particle size (which has an automatic commensurate effect of increased surface area), increased LIC; therefore, ion conductivity of leachate may be a valid indicator of access to plant material for subsequent biological, chemical, or even combustion activity.

However, because particle size fractions of silage had varying chemical composition (tables 1 through 3), comparisons among tables 4 through 7 should be avoided. Similarly, comparisons among harvest methods (columns of tables 4 through 7) should also be avoided because chemical composition of material within a particular size range is affected by harvest method (tables 1 through 3 ). Some means of normalizing conductivity, as an indicator of access to plant nutrients, is needed when chemical composition varies. As Kraus et al. (1999) demonstrated, a ratio of "as is" leachate conductivity to "ultimate" leachate conductivity may be applicable.

\section{CONDUCTIVITY INDEX DENOMINATOR}

Following the approach taken by Kraus et al. (1999), the conductivity index alternatives from equations 2 and 3 with the denominator coming from a sample that was blended or ground through an abrasive cyclone mill, respectively, were considered. LIC data for samples of varying particle size range and varying harvest method (tables 4 through 7) suggest that abrasive cyclone mill processing results in as much ( 10 of 12 cases) or more ( 1 of 12 cases; C, table 4 ) extensive cell damage or membrane leakage than blending.

The comparison of in-lab variability of LIC, within a particle size range for a particular harvest method (table 8), shows that the cyclone mill yielded a more consistent measurement than blending for all particle ranges that were not already uniformly small. While Kraus et al. (1999) found blending to provide a suitable denominator for conductivity index (essentially indicating ultimate or "highest achievable" access), they tested lush wet grass. In this case with dry samples, the abrasive cyclone mill grinding seemed more suitable since the results were more consistent and just as "ultimate."

\section{Harvest Method and Post-Storage Size Reduction}

Heretofore, data have been presented to show that (1) LIC is affected by mechanical processing of a sample, (2) LIC can be an indicator of access to plant nutrients, and (3) abrasive cyclone mill processing provides a consistent and ultimate 
Table 9. Effect of harvest method and subsequent Hobart processing on conductivity index of different particle size fractions of corn silage. [a]

\begin{tabular}{|c|c|c|c|c|}
\hline & \multicolumn{4}{|c|}{ Particle Size ${ }^{[b]}$} \\
\hline & Long & $\begin{array}{l}\text { Medium } \\
\text { Long }\end{array}$ & $\begin{array}{l}\text { Medium } \\
\text { Small }\end{array}$ & Small \\
\hline Chopped & 0.533 & $0.748 \mathrm{abA}$ & $0.876 \mathrm{aAB}$ & $0.994 \mathrm{aB}$ \\
\hline Processed & $0.752 \mathrm{a}$ & $0.677 \mathrm{a}$ & $0.867 \mathrm{a}$ & $0.998 \mathrm{a}$ \\
\hline Shredded & $0.753 \mathrm{aA}$ & $0.835 \mathrm{bcA}$ & $0.864 \mathrm{aAB}$ & $0.964 \mathrm{aB}$ \\
\hline Chopped w/ Hobart & $0.832 \mathrm{a}$ & $0.970 \mathrm{c}$ & $\mathrm{NA}^{[\mathrm{c}]}$ & NA \\
\hline Processed w/ Hobart & $0.975 \mathrm{~b}$ & $0.932 \mathrm{c}$ & NA & NA \\
\hline Shredded w/ Hobart & $0.981 \mathrm{bA}$ & $0.969 \mathrm{cA}$ & NA & NA \\
\hline
\end{tabular}

[a] Values within a column followed by the same lowercase letter are not different, and values within a row followed by the same uppercase letter are not different (Tukey's method, $\mathrm{p}<0.05$ )

[b] Contents of three sieves $(19,8.1$, and $1.8 \mathrm{~mm})$ and pan of device described by Kononoff et al. (2003).

[c] NA = lower sieve and pan contents were not Hobart processed because of their small particle size.

measure of LIC suitable for being a denominator of an index. To focus on harvest or processing effects, conductivity index data $\left(\mathrm{CI}_{U}\right.$, based on abrasive cyclone mill processing) are presented in table 9.

For small and medium small particles, there were no effects on conductivity index by harvest method (table 9; $\mathrm{p}>$ 0.05). Small particles had conductivity indices ranging from 0.964 to 0.998 . Medium small particles had indices ranging from 0.864 to 0.876 . These small particles were not Hobart processed because of their (already small) size.

Chopping and processing $(\mathrm{P})$ led to the lowest conductivity index (0.677) of medium long particles among harvest methods (table 9). Medium long particles from $\mathrm{C}$ had a slightly higher $(0.748)$, although not statistically $(p>0.05)$ different, index. The same size range particles from $\mathrm{S}$ had an index of 0.835 , which was significantly higher $(p<0.05)$. Based on LIC, shredding resulted in as much as and more access to plant nutrients in particles of this size range than $\mathrm{C}$ and $\mathrm{P}$, respectively.

In the long particle size range, samples from $\mathrm{C}$ yielded the lowest conductivity index (0.533; table 9$)$. Both P (0.752) and $S(0.753)$ resulted in higher $(\mathrm{p}<0.05)$ indices, indicating that longitudinal shredding increases access to the plant nutrients within large particles.

The Hobart lab processing was intended to simulate animal chewing or other biorefinery post-storage size reduction. For the medium long particle size range, Hobart processing increased conductivity index significantly for $\mathrm{C}(0.748$ to $0.970)$ and $P(0.677$ to 0.932$)(\mathrm{p}<0.05)$ but insignificantly for $\mathrm{S}(0.835$ to $0.969 ; \mathrm{p}<0.05)$. The insignificant increase in conductivity index due to Hobart processing of particles that were shredded initially indicates that shredding yields particles that, although long, lend good access to plant constituents.

The lack of a significant $(\mathrm{p}>0.05)$ difference between $\mathrm{C}$ plus Hobart processing (0.970) and S without Hobart processing $(0.835)$ for the medium long particle size range is important. The single harvest operation of $\mathrm{S}$ yielded as much access for subsequent activity as the much more energy and time intensive combination of $\mathrm{C}$ plus post-harvest Hobart processing.

Evaluation of the increase in conductivity index due to Hobart processing of long particle size fractions yielded similar conclusions. While there was an increase in index due to Hobart processing regardless of harvest method (table 9; $\mathrm{p}<$
$0.05)$, the boost in index for long particles from $\mathrm{S}(30 \%)$ and $\mathrm{P}(30 \%)$ was less than that of $\mathrm{C}(56 \%)$; furthermore, $\mathrm{C}$ plus Hobart processing resulted in a $15 \%$ lower conductivity index (0.832) of long particles than either $\mathrm{P}$ or $\mathrm{S}$ plus Hobart processing (0.975 and 0.981 , respectively).

Within-row differences in table 9 are indicated with uppercase letters and indicate the effect of particle size, within a harvest method, on conductivity index. There were much larger differences in conductivity index among particle sizes for $\mathrm{C}(0.533$ to 0.994$)$ than for either $\mathrm{P}(0.677$ to 0.998$)$ or $\mathrm{S}$ (0.753 to 0.964$)$. With $\mathrm{C}$ or $\mathrm{P}$, there were differences in conductivity index $(\mathrm{p}<0.05)$ among particle size ranges, even after post-storage Hobart processing. With S, conductivity index was similar among all particle sizes $(\mathrm{p}<0.05)$, except small particles (0.964) had a higher index than long $(0.753)$ and medium long (0.835) particles (table 9).

Shredding is as good as or better than $\mathrm{C}$ or $\mathrm{P}$ with regard to activity access for subsequent biochemical action, depending on the particle size fraction considered. Considering the observation of Shinners et al. (1987) that longitudinal shear takes less energy, shredding appears to be the harvest and particle size reduction method of choice with regard to energy and power as well as animal nutrition or bioprocessing and/or conversion. A dry mass weighted average conductivity index was computed based on percentage of mass in each particle size fraction, moisture content of each particle size fraction, and conductivity index of each particle size fraction. Without considering Hobart processing, which would be very expensive on an industrial scale, these weighted average estimates were $0.725,0.769$, and 0.808 for $\mathrm{C}, \mathrm{P}$, and $\mathrm{S}$, respectively. Despite the much higher mass percentage of long material in shredded silage (fig. 1), the weighted average activity access indicator of conductivity index is higher because of the much higher conductivity of the longer particles (table 9).

\section{Conclusions}

Post-storage Hobart processing increased LIC from long particles harvested by all three harvest methods. Hobart processing increased LIC of medium long particles harvested by $\mathrm{C}$, but not $\mathrm{P}$ nor $\mathrm{S}$. In addition, laboratory grinding with an abrasive cyclone mill or blending of the biomass slurry increased LIC of all samples having long and medium long particles.

LIC could be an activity access or surface area to mass ratio indicator. It increased as particle size decreased and is a rapid and repeatable measure that can uncover differences among lab treatments and harvest methods. Normalizing conductivity measures to account for varying physical (and hence chemical) composition among samples allows comparisons of harvest or process treatments.

Abrasive cyclone mill processing with a $1 \mathrm{~mm}$ screen provided a better denominator for conductivity index than blending. With all particle sizes, the variation in conductivity measures was lower with abrasive cyclone mill processing than blending and extent was comparable.

Shredding increased activity access compared to chopping or chopping and mechanical processing. For large particles, conductivity index was as high or higher for shredding than the other harvest methods. For small particles, harvest method had no effect on conductivity index. Post-storage Hobart processing increased conductivity index of long particles 
harvested by all three harvest methods. Hobart processing increased conductivity index of medium long particles harvested by chopping or chopping and processing, but not shredding.

The weighted (by fraction in each particle size range) average conductivity index was highest $(0.808)$ for shredding and lowest $(0.725)$ for chopping.

\section{REFERENCES}

AOAC. 1990. Official Methods of Analysis. 15th ed. Washington, D.C.: Association of Official Analytical Chemists.

Goering, H. K., and P. J. Van Soest. 1970. Forage fiber analyses (apparatus, reagents, procedures, and some applications). Agric. Handbook No. 379. Washington, D.C.: USDA-ARS.

Hoover, L. L. 1998. Effects of pre-ensiled processing on nutritive quality, digestibility, particle size distribution, and compaction of corn silage. MS thesis in Agricultural Engineering. University Park, Pa.: Penn State University.

Joy, P., and R. Lada. 2006. Crack development in individually quick frozen cut and peel carrots. J. Food Sci. 71(9): E392-E397.
Kononoff, P. J., A. J. Heinrichs, and D. R. Buckmaster. 2003. Modification of the Penn State forage and total mixed ration particle separator and the effects of moisture content on its measurements. J. Dairy Sci. 86(5): 1858-1863.

Kraus, T. J., R. G. Koegel, R. J. Straub, and K. J. Shinners. 1999. Leachate conductivity as an index for quantifying level of forage conditioning. Trans. ASAE 42(4): 847-852.

Marks, B. P., and R. L. Stroshine. 1998. Relating electrolyte leakage to shelled corn storability. Cereal Chem. 75(5): 651-655.

Rajasekaran, L. R., and T. J. Blake. 1999. New plant growth regulators protect photosynthesis and enhance growth under drought of jack pine seedlings. J. Plant Growth Regul. 18(4): 175-181.

Shinners, K. J., R. G. Koegel, G. P. Barrington, and R. J. Straub. 1987. Evaluating longitudinal shear as a forage maceration technique. Trans. ASAE 30(1): 18-22.

Thiaw, S., and A. E. Hall. 2004. Comparison of selection for either leaf-electrolyte-leakage or pod set in enhancing heat tolerance and grain yield of cowpea. Field Crops Res. 86(2-3): 239-253.

Zhang, M., M. L. Sword, D. R. Buckmaster, and G. R. Cauffman. 2003. Design and evaluation of a corn silage harvester using shredding and flail cutting. Trans. ASAE 46(6): 1503-1511.

Zhaohu, L., R. H. Walker, G. Wehtje, and H. G. Hancock. 2000. Using electrolyte leakage to detect soybean (Glycine max) cultivars sensitive to sulfentrazone. Weed Tech. 14(4): 699-704. 